\title{
Peran Self-Compassion terhadap Dimensi-dimensi Kualitas Hidup Kesehatan pada Remaja Panti Asuhan
}

\author{
Annisa Zahra Kawitri, Ratih Arruum Listiyandini, Rina Rahmatika \\ Fakultas Psikologi, Univesitas YARSI, Jakarta, Indonesia \\ e-mail: ratih.arruum@yarsi.ac.id
}

\begin{abstract}
The purpose of thi study is to examine whether self-compassion can predict the level of healthrelated quality of life (HRQoL) among adolescents who live in foster care. The study used quantitative method with cross-sectional design. The sample were 140 teenagers recruited using convenience sampling technique from several foster care in Bekasi and Jakarta. Self Compassion Scale (SCSC) and KIDSCREEN-27 instrument were used to measure the level of self-compassion and HRQoL. Regression test was found that the influence of self-compassion toward HRQoL is significant on the dimension of physical wellbeing, psychological wellbeing, parent relations and autonomy, and school environment. However, self-compassion did not have significant influence toward health-related quality of life on the dimension of social support and peers. The role of self-compassion toward HRQoL implied that adolescents living at foster care need to develop a compassionate attitude for theirself in order to achieve better HRQoL.
\end{abstract}

Keywords: adolescents, Health-Related Quality of Life (HRQoL), self-compassion, foster care

\begin{abstract}
Abstrak
Tujuan penelitian ini untuk menguji sejauhmana self-compassion dapat memprediksi tingkat kualitas hidup kesehatan pada remaja yang tinggal di panti asuhan. Penelitian menggunakan metode kuantitatif desain cross-sectional. Sampel adalah 140 remaja yang diambil dengan menggunakan teknik convenience sampling dari beberapa panti asuhan yang ada di Bekasi dan Jakarta. Skala Self-compassion dan KIDSCREEN-27 digunakan untuk mengukur self-compassion dan kualitas hidup kesehatan. Hasil uji regresi menemukan bahwa pengaruh self-compassion terhadap kualitas hidup kesehatan remaja adalah signifikan pada dimensi kesejahteraan fisik, psikologis, hubungan dengan orang tua dan otonomi, serta lingkungan sekolah. Namun demikian, pengaruh self-compassion ditemukan tidak signifikan pada dimensi dukungan sosial dan teman sebaya. Pengaruh self-compassion di dalam peningkatan berbagai domain kualitas hidup kesehatan mengindikasikan pentingnya pengembangan sikap welas asih terhadap diri sendiri bagi remaja panti asuhan dalam rangka peningkatan kualitas hidup mereka.
\end{abstract}

Kata Kunci: remaja, kualitas hidup kesehatan, self-compassion, panti asuhan

\section{Pendahuluan}

Masa remaja merupakan periode peralihan diantara masa kanak-kanak dan dewasa, yang ditandai dengan adanya perkembangan dalam domain psikososial, kognitif, maupun biologis (Papalia dkk., 2008). Pada masa ini, remaja diharapkan mampu menjalin hubungan dengan teman sebaya secara lebih matang, belajar menerima diri, bertanggung jawab, mandiri secara emosi, menerapkan nilai sistem etika bertingkah laku, dan mempersiapkan diri untuk berkarier (Sihotang dkk., 2013). Tercapainya tugas perkembangan tersebut akan mendukung remaja untuk lebih mampu menggapai kebahagiaan, penerimaan lingkungan, serta mampu mencapai keberhasilan dalam tugas perkembangan pada masa selanjutnya.

Agar tugas perkembangan remaja dapat tercapai dengan baik, maka keberadaan keluarga dibutuhkan. Menurut Tricahyani dan Widiasavitri (2016), keluarga berperan penting untuk memben- 
tuk pengalaman dan kemampuan dalam berkontribusi di masyarakat. Sebagai unit sosial terkecil, keluarga membentuk kepribadian, sikap, dan dasar di dalam perkembangan masa depan (Soekanto, dalam Lazarusli dkk., 2014). Sayangnya, tidak semua remaja memperoleh kondisi yang baik. Kematian, perceraian, kemiskinan, atau keadaan keluarga tidak harmonis menyebabkan orang tua tidak mampu memberikan serta memenuhi kebutuhan hidup remaja. Kondisi ini membuat peran keluarga menjadi menghilang atau tidak sepenuhnya diperoleh hingga membuat sebagian remaja terpaksa menjalani hidup di panti asuhan (Mazaya \& Supradewi, 2011).

Remaja panti asuhan adalah mereka yang berusia 11 sampai 18 tahun yang tinggal di suatu kelembagaan kesejahteraan sosial yang disebut sebagai panti asuhan. Mereka dapat tinggal di panti disebabkan berbagai latar belakang, diantaranya karena orang tua yang meninggal atau bercerai, miskin, keluarga kurang harmonis, ataupun hal lain yang menyebabkan ketidakmampuan orang tua dalam pemenuhan kebutuhan anak (Mazaya \& Supradewi, 2011). Di panti asuhan, sosok pengasuh menggantikan orang tua untuk membantu pemenuhan kebutuhan anak. Pengasuh di panti asuhan memiliki tugas dan tanggung jawab diantaranya adalah menjaga, mengasuh, melindungi, merangkul, dan memberikan rasa aman (Pioh dkk., 2015).

Terkait dengan keberadaan panti asuhan, pada tahun 2008 Kementerian Sosial Republik Indonesia menyatakan bahwa di Indonesia, jumlah panti asuhan berkisar antara 5.000 hingga 8.000 untuk kurang lebih 1.4 juta anak (Gandaputra, 2009). Sudrajat (2009) juga mengungkapkan bahwa lebih dari $90 \%$ lembaga yang ada dikelola oleh institusi berbasis agama. Hartati dan Respati (2010) menyatakan bahwa mengacu pada data dari lembaga Unicef, "Save The Children", serta Departemen Sosial, bahwa sebagian besar (94\%) penghuni panti asuhan adalah karena masalah ekonomi dan hanya sekitar 6\% yang merupakan anak-anak asuh dengan status salah satu orang tua meninggal maupun yatim piatu.

Jumlah pengasuh panti asuhan seringkali tidak sebanding dengan beban pengasuhan yang cukup tinggi. Oleh sebab itu, para pengasuh terpaksa memberikan perhatian secara bergantian. Banyaknya anak yang harus diperhatikan pada akhirnya membuat kualitas perhatian juga berkurang (Sandri, 2015). Dengan kondisi ini, remaja panti asuhan menjadi lebih rentan mengalami kondisi stres jika dibandingkan dengan remaja lainnya yang bukan merupakan penghuni panti asuhan (Sandri, 2015).

Peneliti melakukan sebuah studi pendahuluan sebagai data tambahan untuk menggali fenomena remaja panti asuhan. Studi awal dilakukan oleh peneliti pada 2 April 2017 dan ditemukan bahwa hilangnya sosok orang tua pada remaja panti asuhan menimbulkan perasaan terbuang di usia dini. Mereka menganggap telah dipisahkan dari orang tua dan atau keluarganya untuk tinggal di panti asuhan. Keberpisahan ini membuat remaja merasa terbuang. Perasaan terbuang ini mengindikasikan pengalaman stres traumatik yang jika tidak ditangani lebih lanjut dapat sulit dilupakan, hingga berdampak pada kondisi psikologis jangka panjang (Yosep dkk., 2009). Pengalaman traumatik dan stres peristiwa kehidupan yang dialami para remaja panti asuhan perlu menjadi perhatian khusus karena apabila individu kesulitan dalam menghadapi stressor, maka akan timbul berbagai keluhan, khususnya dalam aspek psikologis remaja (Yosep dkk., 2009).

Lebih jauh lagi, menurut Wuon dkk. (2016) apabila remaja di panti asuhan belum mampu menerima kondisi dirinya dengan dunia baru, maka mereka akan terancam kehilangan identitas sebagai remaja. Pengalaman traumatik atau stres peristiwa kehidupan ditemukan dapat membuat seseorang mengalami penurunan dalam fungsi kesehatan mental dan kualitas 
hidup kesehatan secara keseluruhan (Moore dkk., 2014).

Organisasi kesehatan dunia (World Health Organization) menyatakan bahwa kondisi kualitas hidup melibatkan penilaian individu mengenai keberadaannya di dalam lingkungan sosial, berdasarkan konteks kultur ataupun nilai yang berlaku di masyarakat. Kualitas hidup berhubungan dengan pandangan mengenai hidup secara multidimensi, namun tidak terbatas hanya fisik, melainkan juga dari sisi psikologis (Ogden, 2007). Salah satu aspek kualitas hidup yang perlu menjadi perhatian adalah health-related quality of life (HRQoL), atau kualitas hidup yang berkaitan dengan kesehatan, yaitu persepsi seseorang mengenai level kualitas kesehatannya dalam berbagai aspek baik psikologis, sosial, serta kesehatan fisik. Kualitas hidup kesehatan adalah salah satu yang sering diukur pada pasien dan masyarakat, serta relevan dengan semua kondisi kesehatan (Ravens-Sieberer dkk., 2013). Di dalam penelitian ini, peneliti akan berfokus pada kualitas hidup kesehatan yang dimiliki oleh remaja panti asuhan.

Kualitas hidup kesehatan digambarkan ke dalam lima aspek. Aspek yang dimaksud terdiri dari aspek kesejahteraan psikologis, kesehatan fisik, adanya kemandirian atau hubungan dengan orang tua, dukungan sosial, dan lingkungan sekolah (RavensSieberer dkk., 2013). Von Rueden, dkk. (2006) menyatakan bahwa kualitas hidup kesehatan yang dianggap memadai pada seorang remaja dapat dicirikan dengan memiliki tingkat aktivitas fisik yang baik, seperti kemampuan melakukan aktivitas fisik di sekitar rumah dan sekolah, bermain, olahraga, kapasitas untuk melakukan kegiatan fisik atau energik. Remaja tersebut juga dicirikan memiliki emosi positif dan kepuasan dengan hidup, tidak merasakan kesepian dan kesedihan, kualitas interaksi yang baik dengan orang tua atau walinya, memiliki kemandirian dan sumber daya keuangan yang memadai. Remaja dengan kualitas hidup kesehatan yang baik juga memiliki kualitas interaksi yang baik dengan teman sebayanya sehingga dapat memperoleh dukungan sosial, memiliki persepsi positif terhadap lingkungan sekolahnya (von Rueden dkk., 2006).

Hasil penelitian sebelumnya menemukan bahwa populasi rentan seperti remaja di panti asuhan mengalami kesulitan untuk berhubungan secara positif dengan orang lain, seperti enggan untuk menjalin kontak, menyendiri secara berkepanjangan, bermusuhan, atau lebih egosentris (Sandri, 2015). Penyataan ini didukung oleh Hartini (dalam Mazaya \& Supradewi, 2011) yang juga menemukan bahwa remaja panti asuhan cenderung tidak percaya diri, tidak ingin terlalu terlibat dengan lingkungan, mudah takut, cemas, dan kehilangan harapan masa depan. Lebih lanjut, remaja panti asuhan juga ditemukan kekurangan asupan gizi sehingga kesehatan fisiknya buruk, cenderung dependen atau merasa tidak aman, dan termarjinalkan (Dalimunthe, dalam Ahyani, 2016).

Emosi dan persepsi yang negatif mengenai diri sendiri pada remaja panti asuhan, seperti merasa tidak aman dan terpinggirkan, apabila tidak teratasi dikhawatirkan akan berpengaruh terhadap kesehatan mental mereka. Sebaliknya, remaja akan lebih mampu mengelola emosi negatif apabila memiliki penerimaan diri apa adanya (Sarwono, 2000). Dengan demikian, mereka perlu belajar untuk bersikap menerima berbagai pengalaman baik maupun buruk yang dimilikinya, tidak menghakimi diri secara berlebihan, dan menyadari keterbatasannya sebagai manusia. Penerimaan diri sepenuhnya dengan penuh kasih sayang dan tidak menghakimi terkait dengan variable dalam Psikologi Positif, yang dikenal sebagai self-compassion.

Jika ditinjau dari definisinya, selfcompassion menggambarkan sikap baik terhadap diri sendiri, dengan tidak mengkritik secara berlebihan terhadap kekurangan, kondisi, dan pengalaman pribadi (Neff, 2016). Menurut Neff (2016) self-compassion yang tinggi pada diri 
individu akan ditunjukkan dengan adanya sikap yang baik dalam memandang diri (self-kindness), merasa bahwa kekurangan dan keterbatasan yang dimiliki merupakan bagian dari menjadi manusia normal (common humanity), dan sadar penuh terhadap kondisi yang mereka alami (mindfulness). Sebaliknya, jika seseorang mempunyai self-compassion rendah, ia cenderung akan menilai diri sendiri secara buruk (self-judgement), tidak memahami bahwa ia bagian dari manusia lainnya (isolation), dan secara berlebihan mengkritik dirinya sendiri (overidentification).

Remaja dengan self-compassion yang baik memiliki karakter yang tenang, empati, peka, hangat dan sabar dalam menyelesaikan berbagai masalah. Saat menghadapi kegagalan, mereka tidak akan menyalahkan diri sendiri, berusaha memperbaiki perilaku salah yang dilakukan, sehingga menjadi lebih produktif dan siap menyelesaikan kesulitan yang baru (Hidayati, 2014). Gouveia dkk. (2013) mengemukakan bahwa terdapat hubungan positif dan signifikan antara selfcompassion dengan pandangan yang lebih positif akan kualitas kesehatan fisik, psikologis, sosial, dan lingkungan.

Berdasarkan hasil studi awal, 70\% dari 12 sampel remaja di panti asuhan merasa bahwa orang lain lebih bahagia daripada dirinya sendiri. Artinya, sebagian besar remaja di panti asuhan merasa bahwa mereka belum merasa cukup bahagia dengan kondisinya saat ini di panti asuhan. Adanya peraturan ketat juga memunculkan tekanan psikologis tersendiri. Namun yang menarik, hasil wawancara awal peneliti mengungkapkan bahwa, remaja yang awalnya merasa terbuang tampak dapat berproses seiring dengan berjalannya waktu untuk mampu menerima keadaan dirinya sendiri yang harus hidup di panti asuhan tanpa keluarga.

Self-compassion melibatkan sikap yang sehat terhadap diri sendiri tanpa penilaian serta memahami kekurangan dan rasa sakit yang dialaminya secara psikologis (Gouveia dkk., 2013). Diprediksi bahwa remaja di panti asuhan dengan selfcompassion yang baik akan mampu bersikap tenang, empatik, sabar, peka dan secara terbuka menghadapi masalah yang muncul. Mereka akan lebih mudah menerima diri apabila menghadapi kegagalan, berusaha memperbaiki kesalahan, bersikap produktif, dan bersikap welas asih mengenai pengalaman negatif ataupun rasa sakit yang mereka alami dalam hidup.

\section{Kualitas Hidup Kesehatan}

Ravens-Sieberer dkk. (2013) mengemukakan bahwa kualitas hidup kesehatan merupakan suatu konstruk bersifat multidimensional yang mengukur persepsi diri individu mengenai kesejahteraan psikologis, harga diri, citra tubuh, fungsi kognitif, mobilitas, energi/ vitalitas, serta hubungan sosial dan fungsi keluarga berdasarkan aspek kesehatan fisik, psikologis, sosial dan perilaku yang dirasakan oleh individu.

Dimensi pertama dari kualitas hidup kesehatan adalah kesejahteraan fisik, yaitu dimensi yang mengukur tingkat aktivitas fisik, energi dan kebugaran individu serta sejauhmana individu merasa tidak sehat dan merasakan keluhan bahwa kesehatannya buruk. Kedua adalah kesejahteraan psikologis, merupakan dimensi yang mengukur emosi positif dan kepuasan dengan hidup serta tidak adanya perasaan seperti kesepian dan kesedihan. Ketiga adalah hubungan dengan orang tua dan kemandirian merupakan dimensi yang mengukur kualitas interaksi antara individu dengan orang tua atau walinya serta mengukur apakah individu merasa dicintai dan didukung oleh keluarga. Selain itu, dimensi ini juga mengukur tingkat kemandirian dan tingkat kualitas sumber keuangan individu. Keempat adalah dukungan sosial dan teman sebaya, merupakan dimensi yang mengukur kualitas interaksi antara individu dengan teman sebaya serta dukungan sosial yang 
dirasakannya. Kelima adalah lingkungan sekolah, merupakan dimensi yang mengukur persepsi individu mengenai pembelajaran dan konsentrasi kemampuan kognitifnya, perasaannya tentang sekolah, serta mengukur pandangan individu tentang hubungan dengan gurunya (RavensSieberer dkk., 2013).

Von Rueden dkk. (2006) menemukan bahwa tingkat sosial ekonomi, faktor risiko kontekstual seperti karakteristik pekerjaan yang merugikan, material yang merugikan, berkurangnya dukungan sosial dan perilaku berisiko terhadap kesehatan, serta kehidupan pada masa anak-anak menjadi prediktor dari status kesehatan individu.

\section{Self-Compassion}

Terkait dengan definisinya, selfcompassion dapat diartikan sebagai sikap kasih sayang dan baik terhadap diri saat terjadi kemalangan, kegagalan, kesalahan, tidak bersikap keras dan menghakimi, terhadap berbagai kelemahan dan kekurangan, dan memahami bahwa pengalaman yang dirasakan terjadi juga pada manusia lainnya (Neff, 2018). Rentang usia 14-18 tahun merupakan masa dimana self-compassion akan mulai berkembang (Neff, 2018).

Terdapat enam dimensi selfcompassion berdasarkan pendapat Neff (2003). Pertama adalah self-kindness, yaitu kecenderungan bersikap baik, memahami keadaan diri sendiri, dan menghindari untuk berlebihan dalam menghakimi kekurangan atau kesalahan yang dilakukan. Kebalikannya adalah self-judgement, yaitu kecenderungan individu untuk bersikap melawan, rendah diri, dan mengkritik diri secara berlebihan. Self-judgment yang tinggi akan mengakibatkan individu menyangkal emosi, pikiran, keinginan, perilaku, dan pentingnya diri sendiri sehingga menilai situasi secara berlebihan. Berikutnya adalah common humanity, yang merupakan keyakinan bahwa semua orang memiliki masalah, membuat kesalahan, merasa tidak mampu dalam beberapa hal, menyadari berbagai tantangan, kegagalan, maupun kesulitan adalah sesuatu yang umum dan wajar terjadi, sehingga mampu melihat kelemahan secara menyeluruh sebagai manusia yang tidak sempurna. Kebalikannya adalah isolation, yaitu perasaan individu yang malu terhadap kesulitan yang ia alami, merasa bertanggung jawab sendiri atas segala kesulitan yang terjadi. Terakhir adalah mindfulness, yang merupakan kesadaran utuh individu dalam menjaga keseimbangan perspektifnya sehingga tidak satupun diabaikan pada aspek kepedulian diri sendiri dibandingkan melakukan kritik yang berlebihan terhadap dirinya sendiri, menerima keadaan apa adanya sehingga tidak dapat mengidentifikasi dengan pikiran atau perasaan yang negatif. Kebalikannya adalah over-identification yang merupakan respon negatif berlebihan ketika dihadapkan pada kegagalan atau masalah, terlalu fokus pada kekurangan diri sehingga memicu rasa cemas bahkan depresi.

Beberapa faktor ditemukan memiliki pengaruh terhadap self-compassion antara lain jenis kelamin (Sun, 2016; Zhang \& Cheng, 2016), tingkat status ekonomi sosial (Stolow, 2016), simtom psikopatologis (Muris, 2016), pengasuhan orang tua (Neff $\&$ McGehee, 2010), the role of parents (Neff \& McGehee, 2010), attachment (Adjani, 2015), budaya dan kepribadian (Hidayati, 2015).

Kajian riset mengenai self-compassion pada populasi rentan, termasuk pada remaja di panti asuhan, dapat dikatakan masih jarang ditemukan di Indonesia. Beberapa penelitian mengenai kualitas hidup kesehatan kebanyakan dilakukan pada individu yang mengalami penyakit kronis, seperti kanker (Bellizzi dkk., 2012; Endarti dkk., 2015), obesitas (Loh dkk., 2015), dan diabetes (Daya dkk., 2016). Dengan demikian, mengkaji bagaimana selfcompassion dapat berpengaruh di dalam kualitas hidup kesehatan pada populasi rentan lain, seperti remaja panti asuhan, menjadi penting untuk dilakukan. 
Dengan demikian, studi ini bertujuan menganalisis sejauhmana self-compassion dapat memengaruhi atau memprediksi berbagai dimensi kualitas hidup kesehatan pada remaja panti asuhan. Peneliti memiliki hipotesis bahwa self-compassion akan memiliki pengaruh signifikan terhadap berbagai dimensi kualitas hidup kesehatan. Studi ini diharapkan dapat berkontribusi pada perkembangan ilmu Psikologi Positif dan Psikologi Kesehatan. Dengan menganalisa seberapa penting peran selfcompassion untuk meningkatkan kualitas hidup kesehatan pada populasi ini, maka hal ini bisa juga menjadi acuan bagi para praktisi psikologi klinis untuk mengembangkan program yang berfokus pada populasi remaja panti asuhan.

\section{Metode Penelitian}

Dalam penelitian ini, metode kuantitatif dengan desain cross-sectional dipilih sebagai pendekatan penelitian. Selain itu, penelitian ini bersifat eksplanatif dan korelasional, yaitu peneliti akan menjelaskan ada tidaknya peran dari selfcompassion remaja panti asuhan di dalam peningkatan kualitas hidup kesehatan yang mereka miliki. Variabel prediktor yang digunakan adalah self-compassion, sedangkan variabel kriterianya adalah kualitas hidup kesehatan.

\section{Partisipan Penelitian}

Populasi penelitian adalah remaja yang tinggal di panti asuhan wilayah Bekasi ataupun Jakarta. Kriteria partisipan adalah mereka yang tinggal menetap di panti asuhan dengan rentang usia 14-18 tahun.

Berdasarkan data, jumlah panti asuhan di seluruh Indonesia diperkirakan mencapai ribuan. Hanya saja, panti asuhan yang berada di DKI Jakarta dan sekitarnya jumlahnya tidak terdata secara akurat. Dengan demikian, peneliti memilih menggunakan teknik non-probability sampling dalam proses pengambilan data berdasakan aksesibilitas dan kesediaan panti (convenience sampling).
Pengambilan sampel dilakukan dengan menghubungi sejumlah panti asuhan sesuai lokasi yang ditargetkan, yang dipilih melalui web Dinas Sosial serta faktor aksesibilitas. Peneliti kemudian meminta kesediaan panti untuk menjadi lokasi penelitian. Dari proses ini, jumlah panti asuhan yang menyatakan kesediaan dan dikunjungi peneliti secara langsung berjumlah 12 panti yaitu 7 panti di wilayah Jakarta (1 milik pemerintah, 6 milik swasta) dan 5 panti di wilayah Bekasi yang seluruhnya dikelola yayasan atau pihak swasta. Tidak terdapat data yang terekam dengan akurat mengenai populasi remaja penghuni panti asuhan di seluruh lokasi, namun dengan teknik pengambilan convenience sampling dari 12 panti asuhan tersebut, diperoleh jumlah sampel sebanyak 140 remaja panti asuhan yang bersedia menjadi partisipan penelitian. Pada proses pengambilan data, seluruh partisipan memberikan persetujuan dengan membaca dan menandatangani informed consent.

\section{Instrumen Penelitian}

Peneliti menggunakan dua alat ukur utama, yaitu Self-Compassion Scale (SCS) serta KIDSCREEN-27. Kedua alat ukur tersebut telah melalui proses adaptasi ke dalam bahasa Indonesia dengan menggunakan prosedur translate, back-translate, refinement, uji keterbacaan, serta expert judgement.

Self-Compassion Scale (SCS) disusun Neff (2003) untuk mengukur variabel selfcompassion. SCS merupakan skala yang dapat diperlakukan sebagai unidimensional dengan menggunakan skor total secara keseluruhan maupun multidimensional dengan menelaah skor per dimensi. Namun demikian, pengujian reliabilitas dapat menggunakan skor total dari seluruh dimensi (Neff dkk., 2017).

Skala memiliki 26 item, dimana terdapat 13 item pada dimensi yang favorable, yaitu self-kindness (5 item), common humanity (4 item), dan mindfulness (4 item), serta 13 item pada 
dimensi yang unfavorable, yaitu selfjudgement (5 item), isolation (4 item), dan over-identification (4 item). Respon yang diberikan terdiri dari 5 poin skala Likert (1= hampir tidak pernah sampai dengan $5=$ hampir selalu). Beberapa contoh item SCS seperti: "Saat gagal meraih sesuatu yang penting bagi saya, saya menjadi diliputi oleh perasaan tidak mampu" (dimensi selfkindness) atau "Saya menolak dan menghakimi kekurangan dan ketidakmampuan yang saya miliki" (dimensi self-judgement).

Skala ini sudah pernah diujicobakan pada populasi berusia dewasa ( $>18$ tahun) dengan hasil yang baik (Febrinabilah \& Listiyandini, 2018). Namun demikian, peneliti melakukan kembali sendiri uji coba alat ukur kepada 70 subjek remaja dan ditemukan bahwa secara keseluruhan SCS memperoleh reliabilitas dan validitas yang memadai, yaitu dengan koefisien reliabilitas seluruh skala sebesar $\alpha=.788$ dan korelasi item-total terkoreksi untuk setiap dimensinya berkisar antara $\mathrm{r}$.it $=.200$ -.745 .

Untuk pengukuran kualitas hidup kesehatan, skala KIDSCREEN-27 dari Ravens-Sieberer dkk. (2005) dipilih sebagai instrumen penelitian. KIDSCREEN-27 terdiri dari 27 item, yaitu: kesejahteraan fisik (5 item, contoh: "Apakah selama ini kamu merasa penuh semangat?"), kesejahteraan psikologis (7 item, contoh: "Pernahkah kamu berada dalam suasana hati yang baik?"), hubungan dengan orang tua dan kemandirian (7 item, contoh: "Apakah selama ini kamu telah mempunyai waktu yang cukup untuk dirimu sendiri?"), dukungan sebaya dan lingkungan sosial (4 item, contoh: "Pernahkah kamu menghabiskan waktu bersama temantemanmu?") serta kondisi kesejahteraan sekolah (4 item, contoh: "Apakah kamu selama ini merasa bahagia di sekolah?”). Respon yang diberikan terdiri dari 5 poin skala Likert yang menggambarkan jawaban mengenai frekuensi kemunculan dari sebuah keadaan $(1=$ tidak pernah hingga $5=$ selalu) ataupun kualitas dari sebuah kondisi hidup yang dirasakan ( $1=$ buruk sampai $5=$ sempurna).

Setelah proses adaptasi bahasa, penilaian ahli, dan uji keterbacaan, peneliti melakukan uji coba skala KIDSCREEN-27 kepada subjek remaja sebanyak 252 orang. Dari hasil uji psikometrik, peneliti memperoleh reliabilitas masing-masing dimensi yang berkisar antara .707 - .767. Hasil uji analisis item juga menunjukkan nilai korelasi item-total terkoreksi (r.it) berkisar antara r.it $=.466-.624$.

\section{Teknik Analisis Data}

Uji regresi sederhana dan uji regresi ganda dipilih untuk menjawab permasalahan penelitian. Data diolah melalui berbagai aplikasi diantaranya adalah Microsoft Excel, SPSS for Windows 20.00, serta JASP 0.8.5 for Windows.

\section{Hasil Penelitian dan Pembahasan}

\section{Karakteristik Partisipan}

Berdasarkan data demografis yang disajikan pada table 1, subjek remaja di panti asuhan mayoritas adalah laki-laki $(52.14 \%)$ dengan rata-rata usia (mean= 15.76) yang sebagian besar berdomisili di wilayah Jakarta (68.57\%). Kondisi ekonomi ditemukan sebagai alasan utama dari para remaja ini tinggal di panti asuhan $(57.14 \%)$. Pada penelitian ini, mayoritas sampel panti asuhan dikelola oleh swasta/ yayasan $(82.14 \%)$. Sebagian besar remaja di panti asuhan menganggap pihak yang menjadi significant others adalah teman $(57.82 \%)$. Adapun penyakit yang pernah diderita paling banyak adalah influenza $(44.28 \%)$. 
Tabel 1

Data Demografis Subjek Penelitian

\begin{tabular}{|c|c|c|}
\hline Variabel & Jumlah & Persentase \\
\hline \multicolumn{3}{|l|}{ Jenis Kelamin } \\
\hline Laki-laki & 73 & $52.14 \%$ \\
\hline Perempuan & 67 & $47.86 \%$ \\
\hline \multicolumn{3}{|l|}{ Usia $(\mu=15.76)$} \\
\hline 14-18 tahun & 140 & $100 \%$ \\
\hline \multicolumn{3}{|l|}{ Domisili } \\
\hline Jakarta & 96 & $68.57 \%$ \\
\hline Bekasi & 44 & $3.43 \%$ \\
\hline \multicolumn{3}{|l|}{ Penyebab } \\
\hline Kondisi ekonomi & 80 & $57.14 \%$ \\
\hline $\begin{array}{l}\text { Salah satu orang tua } \\
\text { meninggal }\end{array}$ & 42 & $30 \%$ \\
\hline $\begin{array}{l}\text { Kedua orang tua } \\
\text { meninggal }\end{array}$ & 6 & $4.29 \%$ \\
\hline Lainnya & 12 & $8.57 \%$ \\
\hline \multicolumn{3}{|l|}{ Agama } \\
\hline Islam & 130 & $92.85 \%$ \\
\hline Kristen Katolik & 1 & $.71 \%$ \\
\hline Kristen Protestan & 9 & $6.42 \%$ \\
\hline \multicolumn{3}{|l|}{ Pengelola Panti } \\
\hline \multicolumn{3}{|l|}{ Asuhan } \\
\hline Yayasan/Swasta & 115 & $82.14 \%$ \\
\hline Pemerintah/Dinas & 25 & $17.86 \%$ \\
\hline Sosial & & \\
\hline \multicolumn{3}{|l|}{ Significant Others } \\
\hline Kerabat & 3 & $2.14 \%$ \\
\hline Orang tua & 8 & $5.73 \%$ \\
\hline Pengasuh & 48 & $34.28 \%$ \\
\hline Teman & 81 & $57.85 \%$ \\
\hline \multicolumn{3}{|l|}{ Penyakit Menular yang } \\
\hline \multicolumn{3}{|l|}{ Pernah di Derita di } \\
\hline \multicolumn{3}{|l|}{ Panti Asuhan } \\
\hline Cacar & 44 & $31.42 \%$ \\
\hline Influenza & 62 & $44.28 \%$ \\
\hline Lainnya & 13 & $9.3 \%$ \\
\hline Tidak pernah & 21 & $15 \%$ \\
\hline
\end{tabular}

Konversi skor individual dilakukan dengan melakukan pembagian dari skor keseluruhan di setiap dimensi yang diperoleh partisipan dengan jumlah itemnya, sehingga dihasilkan rentang penilaian skor 1-5 sesuai dengan bentuk skala Likert. Skor konversi individu ini kemudian dihitung untuk mendapatkan nilai rata-rata kelompok. Dengan demikian, hasil rata-rata skor kelompok dari tiap dimensi kemudian dapat diperbandingkan satu sama lainnya dengan norma yang relatif setara.
Tabel 2

Deskripsi Dimensi Kualitas Hidup Kesehatan

\begin{tabular}{lccccc}
\multicolumn{1}{c}{ Dimensi } & KF & KP & HOK & DST & LS \\
\hline $\begin{array}{l}\text { Rata-rata } \\
\text { konversi }\end{array}$ & 3.62 & 3.25 & 3.09 & 3.39 & 3.76 \\
$\begin{array}{l}\text { Standar } \\
\text { Deviasi }\end{array}$ & .747 & .617 & .830 & .869 & .857 \\
\hline $\begin{array}{l}\text { Keterangan: } \\
\text { KF: Kesejahteraan }\end{array}$ & Fisik; & KP: & Kesejahteraan \\
$\begin{array}{l}\text { Psikologis; HOK: Hubungan dengan Orang tua serta } \\
\text { Otonomi; DST: Dukungan Sebaya; LS: Lingkungan }\end{array}$ \\
$\begin{array}{l}\text { Sekolah }\end{array}$
\end{tabular}

Berdasarkan data pada tabel 2 dapat diketahui bahwa nilai skor rata-rata kelompok paling tinggi terdapat pada dimensi lingkungan sekolah $($ Mean $=3.76$, $\mathrm{SD}=.857)$. Adapun nilai skor rata-rata kelompok paling rendah terdapat pada dimensi hubungan dengan orang tua dan kemandirian $(\mathrm{Mean}=3.09, \mathrm{SD}=.830)$.

\section{Uji Asumsi Statistik}

Peneliti melakukan uji asumsi statistik, berupa uji normalitas dan linearitas, untuk memenuhi syarat melakukan uji regresi. Hasil uji dengan One-Sample KolmogorovSmirnov Test menemukan bahwa data terdistribusi normal $(\mathrm{p}=.395-.843, \mathrm{p}>$ .05). Uji linearitas dilakukan dengan menelaah signifikansi deviation from linearity. Hasilnya ditemukan bahwa selfcompassion membentuk garis yang linear dengan kualitas hidup kesehatan dengan nilai $\mathrm{p}=.182-.057(\mathrm{p}>.05)$.

\section{Uji Hipotesis Self-compassion dan Dimensi-dimensi Kualitas Hidup Kesehatan}

Uji regresi sederhana dilakukan untuk mengetahui peran self-compassion secara keseluruhan terhadap setiap dimensi kualitas hidup kesehatan. Berdasarkan tabel 3, ditemukan bahwa self-compassion berpengaruh signifikan terhadap hampir seluruh dimensi kualitas hidup kesehatan, kecuali pada dimensi dukungan dan teman. Self-compassion berpengaruh dengan nilai $7.6 \%$ untuk kualitas hidup fisik, 5.5\% untuk aspek psikologis, $5.0 \%$ untuk dimensi relasi dengan orang tua dan otonomi, $4.2 \%$ pada kesejahteraan di sekolah. 
Tabel 3

Hasil Uji Hipotesis

\begin{tabular}{lccc}
\multicolumn{1}{c}{ Variabel } & $R$-Square & $\mathrm{F}$ & Sig. \\
\hline SC*Fisik & .076 & 11.32 & .001 \\
SC*Psiko & .055 & 8.234 & .005 \\
SC*Orangtua- & .050 & 7.262 & .008 \\
Otonomi & & & \\
SC*Dukungan & .022 & 3.062 & .082 \\
SC*Sekolah & .042 & 6.055 & .015 \\
\hline
\end{tabular}

Analisis Lanjutan Peran Spesifik Dimensi Self-Compassion terhadap Dimensi Kualitas Hidup Kesehatan

Untuk menelaah lebih lanjut mengenai ada tidaknya peran spesifik dari dimensi self-compassion yang paling berkontribusi terhadap kualitas hidup kesehatan, peneliti melakukan analisis lanjutan dengan menggunakan uji regresi ganda. Ditemukan bahwa meskipun total skor self-compassion secara keseluruhan berperan terhadap hampir setiap dimensi dari kualitas hidup, namun tidak semua dimensi selfcompassion ditemukan memiliki peran yang spesifik terhadap peningkatan kualitas hidup kesehatan.

Beberapa dimensi self-compassion yang ditemukan memiliki peran spesifik positif dan signifikan adalah dimensi common humanity $(\beta=.254, p<.05)$ dan mindfulness $\quad(\beta=.367,<.05) \quad$ terhadap kesejahteraan fisik, dengan kontribusi total sebesar $14.3 \% \quad\left(\mathrm{~F}=3.691, R^{2}=.143, \mathrm{p}=.02\right.$ <.05). Pada dimensi kesejahteraan psikologis, ditemukan bahwa dimensi common humanity berperan spesifik terhadap peningkatan kesejahteraan psikologis $\left(\beta=.272, R^{2}=.124, \mathrm{p}<.05\right)$, dan sebaliknya, over-identification memiliki peran negatif yang signifikan terhadap kesejahteraan psikologis $(\beta=-.300, p<.05)$, dengan kontribusi total sebesar $12.4 \%$ $\left(\mathrm{F}=3.131 ; R^{2}=.124 ; \mathrm{p}<.01\right)$.

Untuk kualitas hidup pada dimensi dukungan orang tua dan otonomi, serta kesejahteraan di sekolah tidak ditemukan peran unik yang siginifikan dari setiap dimensi self-compassion. Hal ini mengartikan bahwa self-compassion hanya bisa berperan pada dimensi kualitas hidup orang tua dan kemandirian, serta sekolah apabila dilihat secara keseluruhan dan tidak mengandalkan hanya pada salah satu dimensi saja.

\section{Pembahasan}

Dari penelitian ini, ditemukan bahwa terdapat pengaruh self-compassion secara signifikan terhadap berbagai dimensi kualitas hidup kesehatan remaja panti asuhan. Dalam hal ini, pengaruh selfcompassion terlihat pada kesejahteraan fisik, psikologis, hubungan dengan pengasuh utama dan kemandirian, serta sekolah. Self-compassion ditemukan tidak berpengaruh secara signifikan terhadap dimensi dukungan. Hal ini hampir sepenuhnya mendukung hasil penelitian sebelumnya bahwa terdapat hubungan positif yang signifikan antara selfcompassion dengan kesejahteraan fisik, psikologis, kualitas sosial, dan lingkungan (Gouveia dkk., 2013).

Peneliti menemukan bahwa terdapat pengaruh signifikan dari self-compassion terhadap kualitas hidup kesehatan dimensi kesejahteraan fisik pada remaja di panti asuhan sebesar $7.6 \%$. Self-compassion dapat terwujud dengan adanya sikap welas asih pada diri sendiri saat menghayati adanya kemalangan, sehingga individu dapat merespon rasa sakit yang dialaminya dengan lebih baik (Neff, 2018). Remaja panti asuhan yang memiliki selfcompassion diindikasikan sebagai individu yang mempersepsikan kesehatannya secara positif, mampu menjalani kegiatan seharihari dengan lebih baik, merasa hidupnya menyenangkan dan penuh semangat karena ia memiliki rasa kasih sayang terhadap dirinya.

Dimensi self-compassion yang ditemukan berpengaruh terhadap kesejahteraan fisik, khususnya yaitu common humanity dan mindfulness. Menurut Neff (2018) common humanity adalah kesadaran individu yang melibatkan pengakuan bahwa setiap individu memiliki masalah, pernah membuat kesalahan, dan 
merasa tidak mampu dalam beberapa hal. Pada remaja panti asuhan, common humanity dibutuhkan untuk memahami bahwa keterbatasan yang mereka miliki adalah bagian dari ketidaksempurnaan sebagai manusia. Dengan demikian, adanya kelemahan secara fisik, masalah kesehatan, dan kekurangan yang dialami remaja di panti asuhan akan dipersepsi sebagai kesejahteraan fisik yang tidak buruk.

Terkait mindfulness, Neff (2018) menyatakan bahwa mindfulness merupakan kesadaran utuh individu dalam menjaga keseimbangan sudut pandang untuk menjadi lebih peduli pada dirinya sendiri. Remaja yang memiliki mindfulness digambarkan sebagai individu yang mampu menerima kenyataan seperti apa adanya, sehingga tidak terlalu teridentifikasi oleh pikiran dan perasaan yang negatif (Savitri \& Listiyandini, 2017). Fourianalistyawati dan Listiyandini (2017) menyatakan bahwa remaja yang mampu menerima berbagai sensasi dan emosi dalam kegiatan sehariharinya dibandingkan dengan mengkritik atau menghakiminya akan lebih mampu menghadapi kecemasan. Remaja yang memiliki mindfulness juga akan menunjukkan kontrol perilaku yang lebih baik, terutama pada aspek becoming aware yaitu kesadaran untuk menerima diri, perilakunya, semua akibat dari perilaku serta mampu untuk mengevaluasi perilaku tersebut (Rahman dkk., 2019). Remaja panti asuhan yang memiliki mindfulness, maka akan mampu menerima segala sensasi tubuhnya, kelemahannya secara fisik apa adanya tanpa ada pikiran dan perasaan negatif terhadap kekurangannya tersebut (Savitri \& Listiyandini, 2017). Forianalistyawati dan Listiyandini (2017) mengatakan bahwa terdapat latihan untuk meningkatkan mindfulness guna mengurangi keluhan-keluhan yang dirasakan secara fisik.

Dalam penelitian ini, diketahui bahwa terdapat $92.4 \%$ faktor selain selfcompassion yang dapat menjelaskan varians kualitas hidup dimensi kesehatan fisik. Peneliti melakukan studi literatur, bahwa pencapaian pendidikan dan rekreasi berhubungan secara signifikan dengan kesejahteraan fisik (Humphreys dkk., 2013). Selain itu, Tokuda dkk. (2009) juga menemukan bahwa individu dengan health literacy yang rendah secara signifikan lebih memiliki kesejahteraan fisik yang lebih rendah pula, dan sebaliknya saat health literacy tinggi, maka kesejahteraan fisik juga lebih tinggi.

Penelitian lain pada sampel klinis berupa gangguan psikosomatik (Gamayanti \& Hidayat, 2019), menemukan bahwa emosi marah berperan bagi rendahnya kualitas hidup mereka. Artinya berbagai aspek dalam kehidupan mereka yang diantaranya terkait kesehatan secara umum serta kesejahteraan fisik, dirasakan menjadi kurang memuaskan disebabkan mereka cenderung bereaksi marah ketika mendapat kritik, baik kemarahan itu diekspresikan secara verbal maupun fisik, ataupun ditekan ke dalam dirinya sendiri.

Selanjutnya, peneliti juga menemukan bahwa pengaruh self-compassion signifikan terhadap kesejahteraan psikologis dengan kontribusi sebesar 5.5\%. Merangkum dari berbagai sumber, individu dengan kesejahteraan psikologis yang tinggi, selain akan terbebas dari tekanan atau masalahmasalah mental, mereka akan selalu sehat dan mampu menjalankan aktivitas seharihari secara optimal, menerima diri, memiliki tujuan hidup, dan memaksimalkan berbagai potensi diri (Brebahama \& Listiyandini, 2016). Hasil penelitian yang menunjukkan adanya pengaruh self-compassion terhadap kualitas hidup kesejahteraan psikologis mengindikasikan bahwa remaja panti asuhan yang bersikap lembut terhadap dirinya dan menerima pengalaman yang dialami, akan memiliki kesejahteraan psikologis yang lebih baik. Konsisten dengan penemuan dari Febrinabilah \& Listiyandini (2016) pada populasi rentan di usia dewasa bahwa apabila individu semakin mengasihi dirinya sendiri, maka ia 
akan lebih mampu mengelola tekanan psikologis yang muncul dalam hidupnya.

Berdasarkan analisis tambahan yang dilakukan oleh peneliti, maka ditemukan dimensi self-compassion yang berpengaruh positif terhadap kesejahteraan psikologis adalah common humanity dan dimensi yang berpengaruh negatif terhadap kesejahteraan psikologis adalah over-identification. Temuan ini konsisten dengan pernyataan Baer dkk. (2012) bahwa terdapat korelasi positif self-compassion dengan keterhubungan sosial, kepuasan akan kehidupan, dan kecerdasan emosional (Baer dkk., 2012), yang merupakan komponen penting dalam kesejahteraan psikologis. Di samping itu, kondisi kesejahteraan psikologis salah satunya dicirikan dengan adanya penerimaan diri yang baik, dengan memandang diri sendiri secara positif, menyadari berbagai kelebihan dan kekurangan, serta mampu melihat kehidupan masa lalu dengan sudut pandang yang positif (Savitri \& Listiyandini, 2017). Penerimaan diri yang baik ini akan bisa muncul apabila seseorang sadar dan menerima semua pengalaman hidupnya (Awaliyah \& Listiyandini, 2017). Jika dikaitkan dengan definisinya, remaja di panti asuhan yang memiliki common humanity akan mampu mengaitkan kelemahannya sebagai bagian dari ketidaksempurnaan yang dimiliki manusia pada umumnya. Dengan kata lain, common humanity membantu remaja panti asuhan untuk lebih mampu menghadapi ketidaksempurnaannya sebagai manusia sehingga dapat meningkatkan penerimaan diri yang merupakan komponen penting dalam kesejahteraan psikologis. Artinya, common humanity membantu remaja panti asuhan untuk mempersepsi hidupnya secara lebih positif karena menganggap sebuah ketidaksempurnaan adalah suatu hal yang manusiawi.

Selain common humanity, ditemukan pula bahwa over-identification berpengaruh signifikan terhadap kesejahteraan psikologis. Over-identification adalah dimensi yang bertolak belakang dengan mindfulness, yaitu sebuah reaksi individu yang berlebihan ketika menghadapi suatu masalah maupun kegagalan (Neff, 2018). Remaja di panti asuhan yang memiliki over-identification akan merasa bahwa hidupnya tidak menyenangkan, stres, cemas, depresi, karena seringkali terpaku pada kesalahan dan kekurangannya. Sebaliknya apabila remaja memiliki rasa kesadaran dan penerimaan seutuhnya terhadap berbagai pengalaman yang dimiliki, ia justru akan menjadi lebih mampu untuk merasa sejahtera (Savitri \& Listiyandini, 2017; Awaliyah \& Listiyandini, 2017).

Lebih lanjut, ditemukan bahwa kualitas hidup kesehatan remaja panti asuhan pada dimensi hubungannya dengan orang tua dan kemandirian juga dipengaruhi oleh self-compassion sebesar 5\%. Kekuatan hubungan emosional remaja dan orang tua dimulai pada masa bayi yang disebut sebagai kelekatan (Ainsworth, dalam Dewi \& Valentina, 2013). Namun berdasarkan penelitian sebelumnya, Syukur (2015) menemukan bahwa remaja di panti asuhan belum cukup memperoleh perhatian dari pengasuh yang menjadi sosok pengganti orang tua. Kondisi kurangnya kualitas perhatian dapat memicu munculnya kondisi stres yang lebih besar pada remaja panti (Sandri, 2015). Apabila remaja panti memiliki self-compassion, meskipun terdapat pengalaman menyakitkan, seperti kehilangan kedua orang tua, mereka akan dapat menerima pengalaman tersebut dengan sepenuh hati tanpa menyalahkan dirinya sendiri. Self-compassion dapat dikatakan sebagai sebuah kesadaran dan sikap peduli saat mengalami kemalangan (Neff, 2018). Dengan adanya selfcompassion, mereka akan memahami bahwa pengalaman buruk merupakan sesuatu yang wajar dialami sebagai bagian dari kehidupan manusia.

Pada penelitian sebelumnya, kemandirian disebut sebagai salah satu tugas perkembangan bagi remaja di panti 
asuhan untuk mempersiapkan diri memasuki masa dewasa sehingga mereka tidak memiliki ketergantungan kepada pengasuhnya (Susilowati, 2011). Remaja di panti asuhan dapat mengembangkan perilaku mandiri melalui sikap inisiatif, berusaha mengatasi kesulitan, secara efektif menemukan solusi, dan pantang menyerah dalam berusaha (Mu'tadin, dalam Susilowati, 2011). Menurut Steinberg dan Lerner (dalam Dewi \& Valentina, 2013), individu yang mandiri adalah mereka yang mampu melakukan sesuatu seorang diri, baik dalam mengelola emosi, perilaku, dan nilai-nilai yang dimiliki. Kondisi pengasuhan, sekolah, serta konteks sosial, urutan kelahiran dan jenis kelamin, merupakan beberapa diantara faktor yang beperan pada kemandirian (Dewi \& Valentina, 2013).

Berikutnya, self-compassion secara keseluruhan juga ditemukan berpengaruh secara signifikan terhadap kualitas hidup kesehatan dimensi lingkungan sekolah dengan kontribusi efektif sebesar $4.2 \%$. Self-compassion dapat digambarkan sebagai cara individu bersikap dengan penuh kasih terhadap dirinya sendiri meskipun mengalami kemalangan ataupun penderitaan (Neff, 2003). Apabila remaja mempunyai self-compassion, ia akan bisa mengatasi semua hambatannya dan bersedia meminta bantuan kepada guru maupun teman ketika mengalami kesulitan di lingkungan sekolahnya. Dalam studi literatur lebih lanjut, peneliti menemukan bahwa lingkungan sekolah sebagai institusi formal menjadi panutan dalam mendidik karakter individu yang dapat disesuaikan berdasarkan tingkat usia perkembangan mental individu (Mulyatiningsih, 2011). Menurut Wang (2010) lingkungan sekolah akan memengaruhi remaja dalam partisipasi di sekolah, identifikasi sekolah dan penggunaan strategi pengaturan diri. Kondisi jauh dan tidak tinggal bersama orang tua menuntut remaja untuk terus menyesuaikan diri dengan lingkungan secara mandiri (Maslihah, 2011).
Lingkungan sekolah dapat dipengaruhi oleh faktor performance goals, mastery goals, prestasi akademik, dukungan otonomi, promotion of discussion dan dukungan guru (Wang, 2010).

Kualitas hidup kesehatan dimensi dukungan ditemukan tidak dipengaruhi oleh self-compassion. Dukungan sosial dimaknai sebagai jumlah teman yang dimiliki individu berdasarkan kepuasannya terhadap dukungan yang ia peroleh (Ogden, 2007). Secara keseluruhan dukungan sosial menunjukkan adanya kenyamanan, kepedulian, harga diri, dan pertolongan yang dilakukan satu sama lain (Ogden, 2007). Menurut Kumalasari dan Ahyani (2012) wujud dari dukungan sosial yang dapat diberikan kepada remaja di panti asuhan adalah mendengarkan keluh kesahnya, memberikan penghargaan positif, memberikan bantuan langsung. Diduga bahwa faktor-faktor tersebut lebih dapat memengaruhi dibandingkan dengan self-compassion.

Berdasarkan analisis gambaran data demografi, sebagian besar remaja panti asuhan pernah mengalami penyakit menular. Dalimunthe (dalam Ahyani, 2016) menyatakan bahwa beberapa masalah yang dapat muncul akibat dari ditempatkannya individu dalam panti asuhan, salah satunya adalah masalah kesehatan, seperti penyakit menular.

Penelitian ini menemukan bahwa kondisi ekonomi ditemukan menjadi penyebab utama remaja harus tinggal di panti asuhan (57.14\%). Hal ini sejalan dengan data dalam "Save The Children" bahwa UNICEF dan Departemen Sosial menemukan lebih dari 90 persen remaja harus tinggal di panti adalah karena kemiskinan. Penelitian sebelumnya juga menyatakan peran keluarga dapat hilang disebabkan ketidakmampuan orang tua dalam memberikan kasih sayang (Mazaya \& Supradewi, 2011). Oleh sebab itu, dapat disimpulkan bahwa selain faktor kondisi keluarga yang tidak berfungsi dengan baik, kondisi ekonomi adalah yang paling umum 
menjadi penyebab anak-anak tinggal di panti asuhan.

Jika meninjau mengenai profil kualitas hidup yang dimiliki remaja panti asuhan, ditemukan bahwa nilai skor rata-rata paling rendah adalah dimensi hubungan dengan orang tua dan kemandirian. Penelitian sebelumnya menemukan bahwa keluarga adalah fondasi awal dalam membentuk kemampuan dan kepribadian individu (Tricahyani \& Widiasavitri, 2016; Lazarusli dkk., 2014). Namun, karena penyebab-penyebab tertentu yang mengharuskan remaja tinggal di panti asuhan sehingga ia terlepas dari kasih sayang orang tua kandung.

Untuk dimensi kualitas hidup yang paling tinggi adalah pada domain lingkungan sekolah. Kondisi remaja di panti asuhan yang harus hidup terpisah dari orang tua dan memiliki kualitas hubungan yang rendah dengan pengasuhnya, menyebabkan mereka cenderung lebih mudah meminta bantuan kepada guru atau teman-teman di sekolah. Remaja di panti asuhan akan mempersepsikan bahwa ia bahagia di sekolah, kegiatan di sekolahnya lancar, mampu berkonsentrasi dan memiliki hubungan yang baik dengan gurunya.

Untuk mendapatkan hasil yang lebih baik, pada penelitian selanjutnya, peneliti dapat memilih sampel remaja panti asuhan yang lebih spesifik, seperti yatim piatu, membedakan secara spesifik jenis panti asuhan antara panti asuhan milik swasta dan panti asuhan milik pemerintah, dan untuk populasi remaja dilakukan uji keterbacaan secara lebih mendalam, menyederhanakan dan menyesuaikan itemitem pada alat ukur self-compassion.

\section{Simpulan}

Penelitian ini menemukan bahwa sebagian besar dimensi dari kualitas hidup kesehatan pada remaja panti asuhan, yaitu pada aspek fisik, psikologis, relasi dengan pengasuh dan otonomi, serta sekolah dapat dipengaruhi oleh self-compassion secara signifikan. Secara khusus, ditemukan bahwa dimensi common humanity dari selfcompassion menjadi faktor penting untuk kesejahteraan fisik serta psikologis, dimensi mindfulness dari self-compassion berperan penting bagi peningkatan kesejahteraan fisik, sedangkan dimensi over-identification dari self-compassion berperan negatif terhadap kesejahteraan psikologis. Untuk dimensi kualitas hidup kesehatan lainnya yaitu relasi dengan pengasuh serta lingkungan sekolah, ditemukan bahwa self-compassion hanya dapat berperan jika ditinjau secara utuh dan tidak berdiri sendiri per dimensi. Berbeda dengan dimensi kualitas hidup kesehatan lainnya, pada dimensi dukungan, selfcompassion per dimensi maupun keseluruhan ditemukan tidak memiliki pengaruh signifikan.

Ditemukannya peran self-compassion terhadap sebagian besar dimensi kualitas hidup kesehatan pada remaja panti mengindikasikan bahwa penting untuk mengembangkan sikap welas asih pada remaja panti asuhan, yang dapat dilakukan dengan berbagai program psikoterapi atau pelatihan.

\section{Daftar Pustaka}

Ahyani, L. N. (2016). Meningkatkan adversity quotient (daya juang) pada anak-anak panti asuhan melalui penguatan sosial support. Jurnal Psikologi Perseptual, 1(1), 53-61.

Azwar, S. (2017). Metode Penelitian Psikologi Edisi II. Pustaka Pelajar.

Awaliyah, A., \& Listiyandini, R. A. (2017). Pengaruh rasa kesadaran terhadap kesejahteraan psikologis pada mahasiswa. Journal Psikogenesis, 5(2), 89-101. https://doi.org/10.24854/jps.v5i2.498

Baer, R. A., Lykins, E. L., \& Peters, J. R. (2012). Mindfulness and selfcompassion as predictors of psychological well-being in long-term meditators and matched nonmeditators. The Journal of Positive Psychology, 7(3), 
https://doi.org/10.1080/17439760.2012 .674548

Bellizzi, K. M., Aziz, N. M., Rowland, J. H., Weaver, K., Arora, N. K., Hamilton, A. S., Oakley-Girvan, I., \& Keel, G. (2012). Double jeopardy? Age, race, and HRQOL in older adults with cancer. Journal of Cancer Epidemiology, 2012. https://doi.org/10.1155/2012/478642

Daya, R., Bayat, Z., \& Raal, F. J. (2016). Effects of diabetes mellitus on healthrelated quality of life at a tertiary hospital in South Africa: A crosssectional study. South African Medical Journal, 106(9), 918-928. https://doi.org/10.7196/SAMJ.2016.v1 06i9.9899

Dewi, A. A. A., \& Valentina, T. D. (2013). Hubungan kelekatan orang tua-remaja dengan kemandirian pada remaja di SMKN 1 Denpasar. Jurnal Psikologi Udayana, 1(1), 181-189.

Endarti, D., Riewpaiboon, A., Thavorncharoensap, M., Praditsitthikorn, N., Hutubessy, R., \& Kristina, S. A. (2015). Evaluation of health-related quality of life among patients with cervical cancer in Indonesia. Asian Pacific Journal of Cancer Prevention, 16(8), 3345-3350. http://dx.doi.org/10.7314/APJCP.2015. 16.8.3345

Febrinabilah, R., \& Listiyandini, R. A. (2016). Hubungan antara selfcompassion dengan resiliensi pada mantan pecandu narkoba dewasa awal. Prosiding Konferensi Nasional Peneliti Muda Psikologi Indonesia, 1(1), 19-28.

Fourianalistyawati, E., \& Listiyandini, R. A. (2017). Hubungan antara mindfulness dengan depresi pada remaja. Journal Psikogenesis, 5(2). 115-122.

https://doi.org/10.24854/jps.v5i2.500

Gamayanti, W., \& Hidayat, I. N. (2019). Marah dan kualitas hidup orang yang mengalami psikosomatik. Jurnal Psikologi, 18(2), 177-186. https://doi.org/10.14710/jp.18.2.177186

Gandaputra, A. (2009). Gambaran selfesteem remaja yang tinggal di panti asuhan. Jurnal Psikologi, 7(2), 72-90.

Gouveia, J., Duarte, C., Matos, M., \& Fráguas, S. (2014). The protective role of self-compassion in relation to psychopathology symptoms and quality of life in chronic and in cancer patients. Clinical Psychology \& Psychotherapy, 21(4), 311-323. https://doi.org/ 10.1002/cpp.1838

Hartati, L., \& Respati, W. S. (2012). Kompetensi interpersonal pada remaja yang tinggal di panti asuhan asrama dan yang tinggal di panti asuhan cottage. Jurnal Psikologi, 10(02).

Hidayati, F. N. R. (2015). Hubungan antara self compassion dengan work family conflict pada staf markas Palang Merah Indonesia Provinsi Jawa Tengah. Jurnal Psikologi Undip, 14(2), 183189.

https://doi.org/10.14710/jpu.14.2.183189

Hidayati, D. S. (2015). Self compassion dan loneliness. Jurnal Ilmiah Psikologi Terapan, 3(1), 154-164. https://doi.org/10.22219/jipt.v3i1.2136

Humphreys, D. K., Goodman, A., \& Ogilvie, D. (2013). Associations between active commuting and physical and mental well-being. Preventive Medicine, 57(2), 135-139. https://doi.org/10.1016/j.ypmed.2013.0 4.008

Kumalasari, F., \& Ahyani, L. N. (2012). Hubungan antara dukungan sosial dengan penyesuaian diri remaja di panti asuhan. Jurnal Psikologi: PITUTUR, 1(1), 19-28.

Lazarusli, B., Lestari, S., Abdullah, G., Sudrajat, R., \& Suciptaningsih, O. A. (2014). Penguatan pengaruh keluarga dalam pembentukan kepribadian anak melalui seminar dan pendampingan masalah keluarga. E-DIMAS, 5. 
Loh, D. A., Moy, F. M., Zaharan, N. L., \& Mohamed, Z. (2015). Disparities in health-related quality of life among healthy adolescents in a developing country: The impact of gender, ethnicity, socio-economic status and weight status. Child: Care, Health and Development, 41(6), 1216-1226. https://doi.org/10.1111/cch.12252

Maslihah, S. (2011). Studi tentang hubungan dukungan sosial, penyesuaian sosial di lingkungan sekolah dan prestasi akademik siswa SMPIT Assyfa Boarding School Subang Jawa Barat. Jurnal Psikologi, 10(2), 103-114. https://doi.org/10.14710/jpu.10.2.103114

Mazaya, K. N., \& Supradewi, R. (2011). Konsep diri dan kebermaknaan hidup pada remaja di panti asuhan. Jurnal Psikologi Proyeksi, 6(2). 103-112. http://doi.org/10.30659/p.6.2.103-112

Moore, R. C., Kaup, A. R., Thompson, W. K., Peters, M. E., Jeste, D. V., Golshan, S., \& Eyler, L. T. (2014). From suffering to caring: A model of differences among older adults in levels of compassion. International Journal of Geriatric Psychiatry, 30(2), 185-191. https://doi.org/10.1002/gps.4123

Muris, P. (2016). A protective factor against mental health problems in youths? A critical note on the assessment of self-compassion. Journal of Child and Family Studies, 25(5), 1461-1465. https://doi.org/10.1007/s10826-0150315-3

Neff, K. D. (2003). The development and validation of a scale to measure selfcompassion. Self and Identity, 2(3), 223-250. https:// doi.org/10.1080/15298860309027

Neff, K. D. (2016). Does self-compassion entail reduced self-judgment, isolation, and over-identification? A response to Muris, Otgaar, and Petrocchi (2016).
Mindfulness, $\quad 7(3), \quad$ 791-797. https://doi.org/10.1007/s12671-0160531-y

Neff, K. D., \& McGehee, P. (2010). Selfcompassion and psychological resilience among adolescents and young adults. Self and Identity, 9(3), 225-240. https:// doi.org/10.1080/15298860902979307

Neff, K. D., Whittaker, T. A., \& Karl, A. (2017). Examining the factor structure of the self-compassion scale in four distinct populations: Is the use of a total scale score justified?. Journal of Personality Assessment, 99(6). 1-12. https://doi.org/10.1080/00223891.2016 .1269334

Neff, K. (2018). Self-Compassion. http://self-compassion.org/the-threeelements-of-self-compassion-2/

Ogden, J. (2007). Health Psychology $4^{\text {th }}$ ed. Mc Graw Hill.

Papalia, D. E., Olds, S. W., \& Feldman, R. D. (2008). Human Development $9^{\text {th }}$ ed. Kencana.

Pioh, E., Posumah, J., \& Tulusan, F. (2015). Implementasi kebijakan pengasuhan anak dalam meningkatkan sumber daya manusia di Panti Asuhan Nazareth Tomohon. Jurnal Administrasi Publik, 2(029).

Rahman, A. A., Permana, L., \& Hidayat, I. N. (2019). Peran mindfulness dalam meningkatkan behavioral self control pada remaja. Jurnal Ilmu Perilaku, $3(2)$, 110-117. https://doi.org/10.25077/jip.3.2.110117.2019

Ravens-Sieberer, U., Gosch, A., Rajmil, L., Erhart, M., Bruil, J., Duer, W., \& Mazur, J. (2005). KIDSCREEN-52 quality-of-life measure for children and adolescents. Expert Review of Pharmacoeconomics \& Outcomes Research, 5(3), 353-364. https://doi.org/10.1586/14737167.5.3.3 53

Ravens-Sieberer, U., Herdman, M., Devine, J., Otto, C., Bullinger, M., Rose, M., \& 
Klasen, F. (2013). The European KIDSCREEN approach to measure quality of life and well-being in children: Development, current application, and future advances. Quality of Life Research, 23(3), 791803. https://doi.org/10.1007/s11136013-0428-3

Sandri, R. (2015). Perilaku bullying pada remaja panti asuhan ditinjau dari kelekatan dengan teman sebaya dan harga diri. Jurnal Psikologi Tabularasa, 10(1).43-57.

Sarwono, S. W. (2000). Psikologi Remaja. Rajawali.

Savitri, W. C., \& Listiyandini, R. A. (2017). Mindfulness dan kesejahteraan psikologis pada remaja. Psikohumaniora: Jurnal Penelitian Psikologi, 2(1), 43-59. https://doi.org/10.21580/pjpp.v2i1.132 3

Sihotang, N., Yusuf, A. M., \& Daharnis, D. (2013). Pengaruh layanan bimbingan kelompok terhadap pencapaian tugas perkembangan remaja awal dalam aspek kemandirian emosional (Studi eksperimen di SMP Frater Padang). Konselor, 2(4), 186-192. https://doi.org/10.24036/020132428980-00

Stolow, D., Zuroff, D. C., Young, J. F., Karlin, R. A., \& Abela, J. R. (2016). A prospective examination of selfcompassion as a predictor of depressive symptoms in children and adolescents. Journal of Social and Clinical Psychology, 35(1), 1-20. https://doi.org/10.1521/jscp.2016.35.1. 1

Susilowati, K., Andayani, T. R., \& Priyatama, A. N. (2012). Hubungan antara konformitas teman sebaya dan konsep diri dengan kemandirian pada remaja Panti Asuhan Muhammadiyah Karanganyar. Jurnal Ilmiah Psikologi Candrajiwa, 1(1).

Syukur, A. (2015). Pengaruh pengasuh membentuk sikap sosioemosional anak
(Studi kasus di panti asuhan). $P G-$ PAUD Trunojoyo, 2(1), 1-7. https://doi.org/10.21107/pgpaudtrunojo yo.v2i1.1806

Tokuda, Y., Doba, N., Butler, J. P., \& Paasche-Orlow, M. K. (2009). Health literacy and physical and kesejahteraan psikologis in Japanese adults. Patient Education And counseling, 75(3), 411417.

https://doi.org/10.1016/j.pec.2009.03.0 31

Tricahyani, I. A. R., \& Widiasavitri, P. N. (2016). Hubungan antara dukungan sosial dengan penyesuaian diri pada remaja awal di panti asuhan kota Denpasar. Jurnal Psikologi Udayana (Edisi Khusus Cultural Health Psychology), 168-176. https://ojs.unud.ac.id/index.php/psikolo gi/article/view/28068/17623

Von Rueden, U., Gosch, A., Rajmil, L., Bisegger, C., \& Ravens-Sieberer, U. (2006). Socioeconomic determinants of health related quality of life in childhood and adolescence: Results from a European study. Journal of Epidemiology and Community Health, 60(2), 130-135. https://doi.org/10.1136/jech.2005.0397 92

Wang, M. T., \& Holcombe, R. (2010). Adolescents' perceptions of school environment, engagement, and academic achievement in middle school. American Educational Research Journal, 47(3), 633-662. https://doi.org/10.3102/000283120936 1209

Wuon, A. S., Bidjuni, H., \& Kallo, V. (2016). Perbedaan tingkat depresi pada remaja yang tinggal di rumah dan yang tinggal di Panti Asuhan Bakti Mulia Karombasan Kecamatan Wanea Manado. Jurnal Keperawatan, 4(2). 18.

Yosep, I., Puspowati, N. L. N. S., \& Sriati, A. (2009). Pengalaman traumatik penyebab gangguan jiwa (skizofrenia) 
Peran Self-Compassion terhadap Dimensi-dimensi Kualitas Hidup Kesehatan pada Remaja Panti Asuhan (Annisa Zahra Kawitri, Ratih Arruum Listiyandini, Rina Rahmatika)

pasien di Rumah Sakit Jiwa Cimahi.

Majalah Kedokteran Bandung, 41(4).

194-200.

http://doi.org/10.15395/mkb.v41n4.2

Zhang, J. W., \& Chen, S. (2016). Selfcompassion promotes personal improvement from regret experiences via acceptance. Personality and Social Psychology Bulletin, 42(2), 244-258. https://doi.org/10.1177/014616721562 3271 
Psympathic, Jurnal Ilmiah Psikologi Juni 2020, Vol. 7, No. 1, Hal. : 1-18 